\title{
KEARIFAN BUDAYA LOKAL MADURA SEBAGAI MEDIA PERSUASIF (Analisis Semiotika Komunikasi Roland Barthes dalam Iklan Samsung Galaxy Versi Gading dan Giselle di Pulau Madura)
}

\author{
Sri Wahyuningsih \\ Universitas Trunojoyo Madura \\ Email: naningunijoyo@yahoo.com
}

\begin{abstract}
This article aims to provide an overview of the cultural wisdom of Madura in advertisement Samsung Galaxy Ivory version by Indonesian celebritis Gading and Giselle in the island of Madura. This study, usin a semiotic analysis of Roland Barthes, tried to unlock the meaning of the signs that are used and reveal the bidden message contained in this advertisement. The author conducted a qualitative study with a research focus on scenes depicting local wisdom of Madurese culture, and then select scenes in advertising that represents local cultural wisdom Madura. Local knowledge of Madurese culture has its own persuasive power. Theme choice by producer of the advertisement is very interesting and has its own character, especially of cattle races, clothing style Madurese, as well as their language and dialect. Madura Island in East Java island region known as the island of salt, and exotic, so well known nationally and internationally. The results of the analysis of mobile phone mentioned found some connotations as follows: (1) the existence of a form of Madurese community thanksgiving in the lens, and (2) cow races, clothing Madura, and language of madurese is indigenous culture of Madura. Keywords: local wisdom, culture Madura, advertising, media persuasive, semiotic communication
\end{abstract}

\begin{abstract}
Abstrak
Artikel ini bertujuan untuk memberikan gambaran tentang kearifan budaya lokal Madura dengan menggunakan analisis semiotika komunikasi Roland Barthes dalam iklan Samsung Galaxi versi selebritis Indonesia Gading dan Giselle, di Pulau Madura. Penelitian ini berusaha membuka makna dari tanda-tanda yang digunakan sekaligus menyingkapkan pesan yang secara tersembunyi terkandung di dalam iklan ini. Untuk itu penulis melakukan penelitian kualitataif dengan fokus pada adegan-adegan yang menggambarkan kearifan lokal budaya Madura, untuk kemudian menyeleksi adegan-adegan dalam iklan yang merepresentasikan kearifan budaya lokal Madura. Kearifan lokal budaya Madura memiliki daya persuasif tersendiri. Pilihan tema budaya Madura oleh produser iklan ini sangat menarik dan mempunyai karakter tersendiri terutama tentang karapan sapi, pakaian adat Madura, serta bahasa maupun logat Madura. Pulau Madura yang berada di wilayah pulau Jawa Timur dikenal sebagai pulau garam, dan eksotik, sehingga dikenal secara nasional maupun internasional. Adapun hasil dari analisis iklan hand phone di atas ditemukan beberapa konotasi sebagai berikut: (1) adanya bentuk syukur masyarakat Madura dalam lensa, dan (2) karapan sapi, pakaian adat Madura, Bahasa Madura merupakan kearifan lokal budaya Madura.
\end{abstract}

Kata Kunci: kearifan budaya lokal, budaya Madura, iklan, media persuasif, semiotika komunikasi

\section{A. Pendahuluan}

Kearifan budaya lokal terbentuk dari cara berpikir dan bersikap dari suatu masyarakat ketika mereka merespon masalah-masalah yang timbul di sekitarnya. Kearifan budaya lokal terbentuk tidak dalam rentang waktu yang panjang melalui perenungan-perenungan dan pengujian-pengujian pada setiap kurun yang dilalui.

Kearifan budaya lokal dalam bahasa asing sering dikonsepsikan sebagai kebijakan setempat (local wisdom), pengetahuan setempat 
(local knowledge), atau kecerdasan setempat (local genious). Kearifan budaya lokal juga dapat dimaknai sebuah pemikiran tentang hidup. Pemikiran tersebut dilandasi nalar jernih, budi yang baik, dan memuat hal-hal positif. Kearifan budaya lokal dapat diterjemahkan sebagai karya akal budi, perasaan mendalam, tabiat, bentuk perangai, dan anjuran untuk kemuliaan manusia. Penguasaan atas kearifan budaya lokal akan mengusung jiwa mereka semakin berbudi luhur.

Haryati Soebadio berpendapat bahwa kearifan lokal adalah suatu identitas/kepribadian budaya bangsa yang menyebabkan bangsa tersebut mampu menyerap dan mengolah kebudayaan asing sesuai watak dan kemampuan sendiri. Menurut Rahyono, kearifan lokal merupakan kecerdasan manusia yang dimiliki oleh kelompok etnis tertentu yang diperoleh melalui pengalaman masyarakat. Artinya, kearifan lokal adalah hasil dari masyarakat tertentu melalui pengalaman mereka dan belum tentu dialami oleh masyarakat yang lain. Nilainilai tersebut akan melekat sangat kuat pada masyarakat tertentu dan nilai itu sudah melalui perjalanan waktu yang panjang, sepanjang keberadaan masyarakat tersebut. ${ }^{1}$

Pada kesempatan ini penulis memfokuskan pada kearifan budaya lokal Madura pada karapan sapi. Karapan sapi merupakan budaya Madura yang turun-temurun dan sangat melegenda, baik pada level nasional maupun internasional. Karapan sapi adalah acara khas masyarakat Madura yang digelar setiap tahun pada Agustus atau September, dan akan di lombakan lagi pada final di akhir September atau Oktober. Pada karapan sapi terdapat seorang joki dan 2 (dua) ekor sapi yang dipaksa untuk berlari sekencang mungkin sampai garis finis. Joki berdiri pada kereta kayu dan mengendalikan gerak lari sapi. Panjang lintasan pacu kurang lebih 100 meter dan berlangsung dalam kurun waktu 10 detik sampai 1 menit. $^{2}$

Budaya Madura karapan sapi sangat menonjol ketimbang budaya Madura yang lainnya. Ini terbukti dari ketertarikan produser iklan, yaitu iklan handphone Samsung Galaxy,

\footnotetext{
1 Farhan Azis Lubis. 2014. Pengertian Kearifan Lokeal. http://pangeranarti.blogspot.com/2014/11/pengertian-kearifan-lokal-lengkap.html, 6 Desember 2014, 3:53.

2 Ina. 2014, http://www.eastjava.com/tourism/pasuruan/ina/bullrace.html, 7 Desember 2014, 4:52.
}

untuk memilihnya sebagai sebuah media iklan. Dalam hal ini, penulis akan melakukan analisis pada iklan tersebut, yakni iklan handphone Samsung Galaxy versi Gading dan Giselle (aktor dan Aktris Indonesia sebagai model iklan) yang sedang berfoto dengan kamera handphone Samsung Galaxy pada karapan sapi ketika berada di area atau lapangan karapan sapi.

Iklan adalah suatu bentuk komunikasi massa komersial yang dirancang untuk mempromosikan pemasaran suatu produk atau jasa, maupun pesan dari suatu lembaga, organisasi, bahkan bisa juga pesan dari seseorang yang mengkampanyekan tentang sesuatu. ${ }^{3}$ Bahwa apa yang ditampilkan dalam iklan handphone Samsung Galaxy, merupakan bagian dari kearifan budaya lokal Madura, yaitu karapan sapi yang mempunyai daya persuasif atau daya tarik tersendiri bagi khalayak atau penikmat iklan televisi.

Iklan handphone Samsung Galaxy menampilkan karapan sapi yang lengkap dengan aksesoris maupun pakaian kepala dan badan saat akan parade pameran pakaian, untuk selanjutnya karapan sapi. Sementara joki karapan sapi memakai atribut sakera, yaitu kaos belang-belang warna putih merah dengan baju celana warna hitam sebagai pakaian khas orang Madura yang dikenal pakaian sakera. Unik dan menarik, demikian alasan produser iklan ketika mengangkat budaya Madura dalam pembuatan iklan tersebut agar dapat diminati oleh khalayak. Artinya, iklan dianggap mempunyai daya magnet atau daya persuasif tersendiri bagi khalayak. Daya Persuasif adalah melebihlebihkan kemampuan media dalam membujuk. ${ }^{4}$ Banyak orang yang menggambarkannya kelewat sederhana bahwa isi media dan respon individu mempunyai hubungan sebab akibat langsung. Mereka akan membayangkan bahwa pemirsa akan melakukan sesuatu sesuai dengan yang dikatakan dalam sebuah iklan. Padahal komunikasi tunggal takkan berpengaruh sekuat itu. Hanya jika sesuatu disampaikan media secara terus-menerus, maka hal itu akan berpengaruh pada perilaku individu. Terbukti iklan handphone Samsung Galaxy versy karapan sapi Madura

\footnotetext{
3 Sri Wahyuningsih. 2013. Desain Komunikasi Visual, Bangkalan, UTM Press. h.129.

4 Rivers, William L,Jay W.Jensen, \& Theodore Peterson. 2004. Media Massa dan Masyarakat Modern. Jakarta. Prenada Media. h. 252.
} 
mempunyai daya tarik secara persuasif. Andre Rompis, VP Divisi Mobile Samsung Indonesia mengatakan bahwa 80 persen pengguna smartphone di Indonesia ternyata menggunakan handphone milik Samsung. ${ }^{5}$

\section{B. Landasan Teori}

\section{Media dan Praktik Representasi}

Representasi merujuk pada bagaimana seseorang, satu kelompok, gagasan, atau pendapat tertentu ditampilkan dalam suatu pesan media, baik dalam bentuk pemberitaan maupun wacana media lainnya. ${ }^{6}$ Representasi penting untuk memahami dua hal, yaitu: (1) apakah seseorang, kelompok, atau gagasan tersebut ditampilkan sebagaimana mestinya atau dimarjinalkan lewat penggambaran yang buruk, dan (2) bagaimana representasi tersebut ditampilkan.

Media menjadi sarana yang efektif untuk mengarahkan atau menghilangkan gagasan orang atau kelompok tertentu, atau sebaliknya dapat pula dimarjinalkan. Sebagai produsen industri informasi, menurut John Fiske berpendapat bahwa setidaknya terdapat tiga proses yang dihadapi para pekerja media tersebut. Level pertama, peristiwa yang ditandakan (encode) sebagai realitas. ${ }^{7}$ Bagaimana realitas tersebut dikonstruksi sebagai realitas oleh media. Dalam bahasa gambar hal ini umumnya berhubungan dengan aspek-aspek spesifik yang tertangkap secara visual seperti pakaian, lingkungan, ucapan, dan ekspresi. Di sini realitas selalu ditandakan, ketika kita menganggap dan mengkonstruksi penandaan tersebut sebagai sebuah realitas.

Level kedua, ketika kita memandang sesuatu sebagai sebuah realitas. Pertanyaan yang muncul adalah bagaimana realitas tersebut digambarkan. Di sini digunakan perangkat secara teknis. Dalam bahasa tulis, perangkat teknis itu adalah kata, kalimat, proposisi, grafik dan sebagainya. Pada bahasa gambar, perangkat tersebut dapat berupa kamera, pencahayaan, sudut pengambilan gambar oleh kamera, editing,

\footnotetext{
Beritateknologi.com, 2013.

Eryanto. 2005. Analisis Wacana: Pengantar Analisis Teks Media, Cetakan Keempat, Yogyakarta. PT LKIS Pelangi Aksara. h. 113.

Basarah, Finy Fitrya. 2006. Poligami Dalam Media Film Indonesia (Analisis Semiotika Roland Barthes Film 'Berbagi Suami'). Universitas Padjadjaran Bandung. Pogram Pascasarjana Program Studi Ilmu Komunikasi. h. 34.
}

dan musik. Penggunaan kata, kalimat, proposisi, atau elemen retoris lainnya dapat memberikan makna tertentu ketika diterima oleh khalayak. Pada level ketiga, adalah bagaimana peristiwa tersebut diorganisir ke dalam konvensi-konvensi yang diterima secara logis. Bagaimana kodekode tersebut dihubungkan dan diorganisasikan ke dalam koherensi sosial seperti kelas sosial, atau kepercayaan dominan yang ada dalam masyarakat. Fiske mengatakan bahwa ketika melakukan representasi tersebut maka akan sulit dihindarinya bias ideologi. Bias ideologi ini sering kali menjelma menjadi kepercayaan sosial yang diterima secara common sense dan tidak lagi dipertanyakan, bahkan oleh para produsen pesan itu sendiri.

Konsep Stuart Hall mengenai proses representasi media adalah konsep encoding/ decoding yang menjelaskan bagaimana proses sebuah peristiwa dimaknai oleh media maupun khalayak media. Hall mengatakan, proses encoding media terhadap suatu realitas tidak terlepas dari aspek-aspek ideologi baik bersifat institusional, personal maupun aspek-aspek yang berkaitan dengan kondisi sosio-kultural. Dalam hal ini, seseorang akan terlibat dengan politik penandaan ketika ia mencoba membuat gambaran tentang realitas. ${ }^{8}$

Dimulai pada proses encoding ini, nilainilai digunakan ketika seseorang memberikan penandaan terhadap sebuah peristiwa. Dalam konsepsi Hall, peristiwa yang telah "ditandai" tersebut diarahkan untuk memiliki tingkat kesesuaian yang baik ketika dipahami oleh khalayak. Yang dimaksud dengan kesesuaian pada proses penerimaan (decode) dalam konsepsi Hall adalah adanya pengaruh " have an effect" baik berupa masukan, hiburan, instruksi, atau ajakan yang tentu saja memiliki kompleksitas aspekaspek perseptual di dalamnya baik yang bersifat kognitif, emosional, ideologis atau konsekuensi behavioral lainnya.

Representasi dianggap membentuk benang sosial dalam hidup masyarakat. Representasi adalah masalah yang penting sebab ia bukan merupakan presentasi atau tampilan langsung dari dunia dan hubungan orang-orang di dalamnya, melainkan representasi yang 
berhubungan dengan proses aktif dalam pemilihan dan penampilan yang melalui proses seleksi dan penyusunan makna yang sedemikian rupa. Jadi, representasi bukan semata, mata penyampaian makna yang sudah ada, melainkan sebuah usaha aktif untuk membuat sesuatu memiliki makna tertentu.

Sejalan dengan apa yang dikatakan Fiske mengenai proses representasi, Eriyanto mengatakan paling tidak ada dua proses yang dilakukan media. Pertama, memilih fakta. Proses memilih fakta ini didasarkan pada asumsi bahwa tidak mungkin media melihat peristiwa tanpa sebuah perspektif. Kedua, menuliskan fakta. Proses ini berkaitan dengan bagaimana fakta yang dipilih tersebut disajikan kepada khalayak. Gagasan ini kemudian diungkapkan melalui bahasa dalam bentuk kata, kalimat, proposisi, juga dengan bantuan aksentuasi bahasa gambar dan komponen grafik lainnya seperti foto, gambar, ilustrasi, serta penebalan huruf yang mewakili sebuah pemaknaan tertentu. ${ }^{\text {? }}$

Pemilihan fakta merupakan juga praktik reprensentasi yang nantinya kemudian akan dibungkus dengan menggunakan bahasa tertentu untuk memapankan definisi media terhadap realitas tersebut. Dalam pemilihan fakta sudah tentu akan terdapat fakta lainnya yang dibuang atau terabaikan. Dengan "bentukan" seperti inilah realiltas media hadir dihadapan khalayak sebagai sebuah wacana. Bahasa tidak hanya mencerminkan realitas, tetapi juga dapat menciptakan realitas itu sendiri.

\section{Semiotika Roland Barthes}

Roland Barthes, sebagai salah satu tokoh semiotika, melihat signifikasi (tanda) sebagai sebuah proses yang total dengan suatu susunan yang sudah terstruktur. Signifikasi itu tidak terbatas pada bahasa, tetapi terdapat pula halhal yang bukan bahasa. Pada akhirnya, Barthes menganggap pada kehidupan sosial, apapun bentuknya, merupakan suatu sistem tanda tersendiri pula. ${ }^{10}$

Semiotika (atau semiologi) Roland Barthes mengacu kepada Saussure dengan menyelidiki hubungan antara penanda dan petanda pada sebuah tanda. Hubungan penanda dan petanda

\footnotetext{
9 Eryanto. 2005. Analisis Wacana: Pengantar Analisis Teks Media, Cetakan Keempat, Yogyakarta. PT LKIS Pelangi Aksara. h. 116.

10 Kurniawan. 2001. Semiologi Roland Barthes. Magelang. Indonesia Tera. h. 53 .
}

ini bukanlah kesamaan (equality), tetapi ekuivalen. Bukannya yang satu kemudian membawa pada yang lain, tetapi korelasilah yang menyatukan keduanya. ${ }^{11}$

Roland Barthes mengungkapkan bahwa bahasa adalah sebuah sistem tanda yang mencerminkan asumsi-asumsi dari suatu masyarakat tertentu dalam waktu tertentu. Barthes sendiri dalam setiap essainya kerap membahas fenomena keseharian yang kadang luput dari perhatian. Barthes juga mengungkapkan adanya peran pembaca (the reader) dengan tanda yang dimaknainya. Dia berpendapat bahwa "konotasi", walaupun merupakan sifat asli tanda, membutuhkan keaktifan pembaca agar dapat berfungsi. ${ }^{12}$

Bagi Barthes, seperti yang ia tuangkan dalam karyanya yang berjudul The Pleasure of The Text (1975), apabila sebuah teks tidak mampu menggetarkan buhul-buhul darah para pembaca, maka teks tersebut tidak akan memiliki arti (meaning) apapun. Suatu teks harus dapat menggelinjang keluar dari bahasa yang dipergunakannya. Barthes mengatakan bahwa, "The world is full of signs, but these signs do not all have the fine simplicity of the letters of the alphabet, of highway signs, or of military uniforms: they are infinitely more complex. (Dunia ini penuh dengan tanda-tanda ini tidak semuanya mempunyai kesederhanaan murni dari huruf-huruf, alfabet, tanda lalu lintas, atau seragam militer: mereka secara takterbatas lebih kompleks)". Sejak Barthes, tidak hanya karya sastra yang dikaji lewat semiotika jenis ini, namun juga merambah ke pelbagai gejala sosial lainnya seperti mode, foto dan film. ${ }^{13}$

Dari peta Barthes di atas terlihat bahwa tanda denotatif (3) terdiri atas penanda (1) dan petanda (2). Akan tetapi, pada saat bersamaan, tanda denotatif adalah juga penanda konotatif (4). Dengan kata lain, hal tersebut merupakan unsur material: hanya jika Anda mengenal tanda "singa", barulah konotasi seperti harga diri, kegarangan, dan keberanian menjadi mungkin. Jadi, dalam konsep Barthes, tanda konotatif tidak sekedar memiliki makna tambahan namun juga mengandung kedua bagian tanda denotatif

\footnotetext{
11 Ibid. h. 22 .

12 Alex Sobur. 2004. Semiotika Komunikasi. Cetakan Kedua. Bandung. PT. Remaja Rosdakarya. h. 63.

13 Ibid. h. 68.
} 
yang melandasi keberadaannya. Sesungguhnya, inilah sumbangan Barthes yang sangat berarti bagi penyempurnaan semiologi Saussure, yang berhenti pada penandaan dalam tataran denotatif.

Daniel Chandler dalam Semiotics for Beginners mengungkapkan bahwa denotasi merupakan tanda tahap pertama, yang terdiri dari penanda dan petanda. Sedangkan konotasi merupakan tanda tahap kedua, yang termasuk di dalamnya adalah denotasi, sebagai penanda konotatif dan petanda konotatif.

Berikut adalah peta tanda dari Roland

\begin{tabular}{|l|l|}
\hline $\begin{array}{l}\text { 1. Signifer } \\
\text { (Penanda) }\end{array}$ & $\begin{array}{l}\text { 2. Signified } \\
\text { (Petanda) }\end{array}$ \\
\hline $\begin{array}{l}\text { 3. Denotative Sign } \\
\text { (Tanda Denotatif) }\end{array}$ \\
$\begin{array}{l}\text { 4. CONNOTATIVE } \\
\text { SIGNIFIER } \\
\text { (PENANDA KONOTATIF) }\end{array}$ & $\begin{array}{l}\text { S. CONNOTATIVE } \\
\text { (PETANDA } \\
\text { KONOTATIF) }\end{array}$ \\
\hline \multicolumn{2}{|l|}{ 6. CONNOTATIVE SIGN (TANDA KONOTATIF) } \\
\hline
\end{tabular}

Gambar 1. Peta Tanda Roland Barthes

Barthes tidak sebatas itu memahami proses penandaan, tetapi dia juga melihat aspek lain dari penandaan, yaitu mitos (myth) yang menandai suatu masyarakat. Mitos (atau mitologi) sebenarnya merupakan istilah lain yang dipergunakan oleh Barthes untuk ideologi. Mitologi ini merupakan level tertinggi dalam penelitian sebuah teks, dan merupakan rangkaian mitos yang hidup dalam sebuah kebudayaan. Mitos merupakan hal yang penting karena tidak hanya berfungsi sebagai pernyataan (charter) bagi kelompok yang menyatakan, tetapi merupakan kunci pembuka bagaimana pikiran manusia dalam sebuah kebudayaan bekerja.

Mitos ini tidak dipahami sebagaimana pengertian klasiknya, tetapi lebih diletakkan pada proses penandaan ini sendiri, artinya, mitos berada dalam diskursus semiologinya tersebut. Menurut Barthes mitos berada pada tingkat kedua penandaan, jadi setelah terbentuk sistem tanda-penanda-petanda, maka tanda tersebut akan menjadi penanda baru yang kemudian memiliki petanda kedua dan membentuk tanda baru. Konstruksi penandaan pertama adalah bahasa, sedang konstruksi penandaan kedua merupakan mitos, dan konstruksi penandaan tingkat kedua ini dipahami oleh Barthes sebagai metabahasa (metalanguage). Perspektif Barthes tentang mitos ini menjadi salah satu ciri khas semiologinya yang membuka ranah baru semiologi, yakni penggalian lebih jauh penandaan untuk mencapai mitos yang bekerja dalam realitas keseharian masyarakat.

Dua tahap penandaan signifikasi (two order of signification) Barthes dapat digambarkan sebagai berikut:

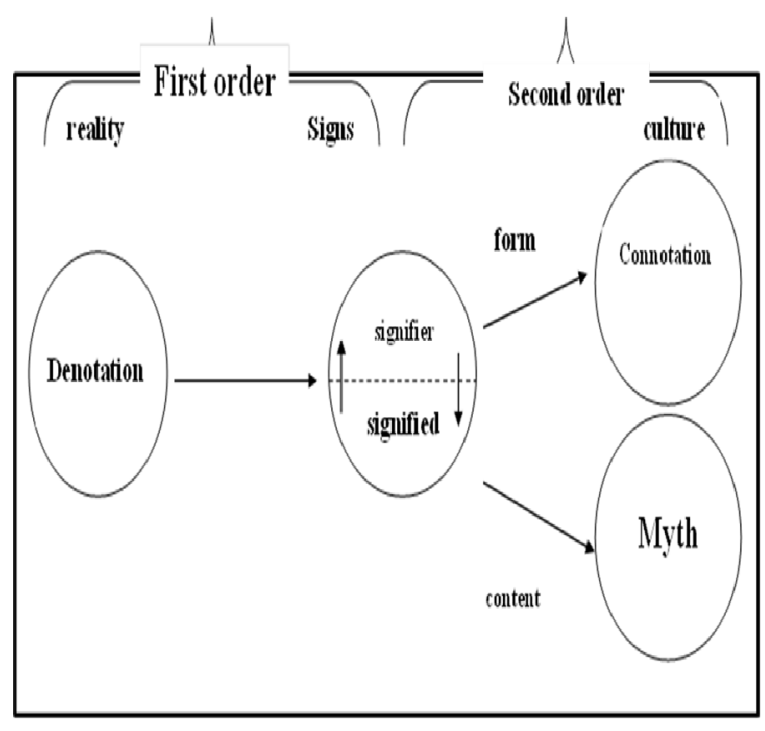

Gambar 2: Signifikasi Dua Tahap Barthes ${ }^{14}$

Melalui gambar ini Barthes, seperti dikutip Fiske, menjelaskan: signifikasi tahap pertama merupakan hubungan antara signifier dan signified di dalam sebuah tanda terhadap realitas eksternal. Barthes menyebutnya sebagai denotasi, yaitu makna paling nyata dari tanda. Konotasi adalah istilah yang digunakan Barthes untuk menunjukkan signifikasi tahap kedua. Hal ini menggambarkan interaksi yang terjadi ketika tanda bertemu dengan perasaan atau emosi dari pembaca serta nilai-nilai dari kebudayaannya. Konotasi mempunyai makna subjektif atau paling tidak intersubjektif. Pemilihan kata-kata kadang merupakan pilihan terhadap konotasi, misalnya kata "penyuapan" dengan "memberi uang pelicin". Dengan kata lain, denotasi adalah apa yang digambarkan tanda terhadap sebuah objek; sedangkan konotasi adalah bagaimana menggambarkannya. ${ }^{15}$

\footnotetext{
14 Alex Sobur. 2003. Semiotika Komunikasi. Cetakan Pertama. Bandung: PT. Remaja Rosdakarya. h.. 69

15 Ibid. h. 128
} 
Pada signifikasi tahap kedua yang berhubungan dengan isi, tanda bekerja melalui mitos (mytb). Mitos adalah bagaimana kebudayaan menjelaskan atau memahami beberapa aspek tentang realitas atau gejala alam. Mitos merupakan produk kelas sosial mengenai hidup dan mati, manusia dan dewa, dan sebagainya. Sedangkan mitos masa kini misalnya mengenai feminitas, maskulinitas, ilmu pengetahuan, dan kesuksesan. ${ }^{16}$

Dalam semiologi Roland Barthes, denotasi merupakan sistem signifikasi tahap pertama, sementara konotasi merupakan sistem signifikasi tahap kedua. Dalam hal ini, denotasi lebih diasosiasikan dengan ketertutupan makna, dan dengan demikian, merupakan sensor atau represi politis. Sedangkan konotasi identik dengan operasi ideologi, yang disebutnya sebagai mitologi (mitos), seperti yang telah diuraikan di atas, yang berfungsi untuk memgungkapkan dan memberikan pembenaran bagi nilai-nilai dominan yang berlaku dalam suatu periode tertentu. Barthes juga mengungkapkan bahwa baik di dalam mitos maupun ideologi, hubungan antara penanda konotatif dengan petanda konotatif terjadi secara termotivasi. ${ }^{17}$

Dalam pengamatan Barthes, hubungan mitos dengan bahasa terdapat pula dalam hubungan antara penggunaan bahasa literer dan estetis dengan bahasa biasa. Dalam fungsi ini yang diutamakan adalah konotasi, yakni penggunaan bahasa untuk mengungkapkan sesuatu yang lain daripada apa yang diucapkan. Baginya, lapisan pertama itu taraf denotasi, dan lapisan kedua adalah taraf konotasi: penandapenanda konotasi terjadi dari tanda-tanda sistem denotasi. Dengan demikian, konotasi dan kesusastraan pada umumnya, merupakan salah satu sistem penandaan lapisan kedua yang ditempatkan di atas sistem lapisan pertama dari bahasa. ${ }^{18}$

Barthes menggunakan konsep connotation-nya Hjemslev untuk menyingkap makna-makna yang tersembunyi. ${ }^{19}$ Konsep ini menetapkan dua pemunculan makna yang bersifat promotif,

19 Alex Sobur. 2006. Semiotika Dalam Tafsir "Harry Potter". Disampaikan dalam Seminar Ilmiah Intern (SII) Dosen Fakultas Ilmu Komunikasi Universitas Islam Bandung. 24 Mei 2006.
}

yakni denotatif dan konotatif, pada tingkat denotatif, tanda-tanda itu mencuat terutama sebagai makna primer yang "alamiah". Namun pada tingkat konotatif, di tahap sekunder, muncullah makna yang ideologis.

Tanda-tanda denotatif dan konotatif yang akan dianalisis dalam penelitian ini adalah adeganadegan yang membawakan pesan-pesan kearifan lokal budaya Madura dalam iklan sebagai media persuasif.

\begin{tabular}{|c|c|}
\hline Penanda (Signifier) & Petanda (Signified) \\
\hline \multicolumn{2}{|l|}{ Pengambilan Gambar } \\
\hline $\begin{array}{l}\text { Big Close Up } \\
\text { Close Up } \\
\text { Medium Shot } \\
\text { Long Shot }\end{array}$ & $\begin{array}{l}\text { Emosi, dramatik, momen penting } \\
\text { Intim, dekat } \\
\text { Hubungan personal dengan } \\
\text { subyek } \\
\text { Konteks, perbedaan publike }\end{array}$ \\
\hline \multicolumn{2}{|l|}{$\begin{array}{l}\text { Sudut Pandang (Angle) } \\
\text { pengambilan gambar }\end{array}$} \\
\hline $\begin{array}{l}\text { High } \\
\text { Eye Level } \\
\text { Low }\end{array}$ & $\begin{array}{l}\text { Dominasi, kekuasaan, otoritas } \\
\text { Kesejajaran, kesamaan, sederajat } \\
\text { Didominasi, dikuasai, kurang } \\
\text { otoritas }\end{array}$ \\
\hline \multicolumn{2}{|l|}{ Tipe Lensa } \\
\hline $\begin{array}{l}\text { Wide Angle } \\
\text { Normal } \\
\text { Telephoto }\end{array}$ & $\begin{array}{l}\text { Dramatis, akan memberikan } \\
\text { pandangan atas keseluruban } \\
\text { keadaan. } \\
\text { Normalitas, keseharian } \\
\text { Tidak personal, voyeuristic }\end{array}$ \\
\hline \multicolumn{2}{|l|}{ Fokus } \\
\hline $\begin{array}{l}\text { Selective focus } \\
\text { Soft focus } \\
\text { Deep focus }\end{array}$ & $\begin{array}{l}\text { Meminta perbatian (lihat yang } \\
\text { ini saja) } \\
\text { Romantis, nostalgia } \\
\text { Semua unsur adalah penting } \\
\text { (lihat semuanya!) }\end{array}$ \\
\hline \multicolumn{2}{|l|}{ Pencahayaan } \\
\hline $\begin{array}{l}\text { High Key } \\
\text { Low Key } \\
\text { High Contrast } \\
\text { Low Contrast }\end{array}$ & $\begin{array}{l}\text { Riang, cerah } \\
\text { Suram, muram } \\
\text { Dramatik, teatrikal } \\
\text { Realistik, documenter }\end{array}$ \\
\hline \multicolumn{2}{|l|}{ Pewarnaan } \\
\hline $\begin{array}{l}\text { Warm (kuning, } \\
\text { oranye, merah, abu- } \\
\text { abu) } \\
\text { Cool (biru, hijau) } \\
\text { Black and White }\end{array}$ & $\begin{array}{l}\text { Optimis, harapan, hasrat, } \\
\text { agitasi } \\
\text { Pesimis, tidak ada harapan } \\
\text { Realisme, aktualitas, faktual }\end{array}$ \\
\hline
\end{tabular}

Gambar 3: Elemen-Elemen dalam Gambar menurut Keith Selby dan Ron Cowdery ${ }^{20}$

Gambar memang memiliki banyak makna. Oleh karena itu, fenomena gambar atau visual ini sangat menarik karena melalui gambar orang awam pun dapat menangkap maksud di

20 Sri Wahyuningsih. 2009. Pesan-Pesan Dakwah Dalam Media Film Indonesia (Analisis Semiotika Roland Barthes Terbadap Film "99 Cabaya Di Langit Eropa). Universitas Padjadjaran Bandung. Program Pascasarjana Program Studi Ilmu Komunikasi. 
balik gambar tersebut, walaupun mungkin saja interpretasinya sangat berbeda dari si pembuat gambar. Hal tersebut disebabkan karena perbedaan latarbelakang budaya, frame of reference, field of experience, dan kemampuan interpretasi setiap orang ikut mempengaruhi bagaimana orang melihat dan menginterpretasikan suatu gambar.

\section{Metodologi Penelitian}

Jenis penelitian ini adalah kualitataif. Objek penelitiannya adalah iklan handphone Samsung Galaxy, dengan fokus penelitian yaitu adeganadegan yang menggambarkan kearifan budaya lokal Madura, yang kemudian akan diseleksi lagi oleh penulis yang manakah adegan-adegan iklan ini yang dapat dikategorikan merepresentasikan kearifan budaya lokal Madura. Dalam penelitian ini, sebuah iklan dipahami sebagai teks, dan dalam sebuah teks sarat akan tanda yang memiliki makna-makna tersendiri. Penelitian ini akan berusaha membuka makna dari tandatanda yang digunakan sekaligus menyingkapkan pesan yang secara tersembunyi terkandung di dalam iklan ini.

Budiman dalam Sobur menjelaskan bahwa pendekatan yang dianggap sesuai dengan penelitian ini adalah pendekatan kualitatif interpretatif dengan analisis semiotika Roland Barthes. Dalam semiologi Roland Barthes, denotasi merupakan sistem signifikasi tahap pertama, sementara konotasi merupakan sistem signifikansi tahap kedua. Dalam hal ini, denotasi lebih diasosiasikan dengan ketertutupan makna, dan dengan demikian, merupakan sensor atau represi politis. Sedangkan konotasi identik dengan operasi ideologi, yang disebutnya sebagai mitologi (mitos), seperti yang telah diuraikan di atas, yang berfungsi untuk mengungkapkan dan memberikan pembenaran bagi nilai-nilai dominan yang berlaku dalam suatu periode tertentu. Barthes juga mengungkapkan bahwa baik di dalam mitos maupun idiologi, hubungan antara penanda konotatif dengan petanda konotatif terjadi secara termotivasi. ${ }^{21}$

Melengkapi penelitian ini data-data diperoleh dari sumber data primer (yaitu kumpulan data yang diperoleh secara langsung

21 Alex Sobur. 2004. Semiotika Komunikasi. Cetakan Kedua. Bandung. PT. Remaja Rosdakarya. h. 70-71. dari isi wacana yang ditampilkan iklan handphone Samsung Galaxy, sedangkan data sekunder (kumpulan data lain yang mendukung penelitian ini, yaitu studi kepustakaan (library research) yang berhubungan terhadap teori, informasi tentang hal-hal yang berkaitan dengan landasan teori, serta konsep-konsep ilmiah yang diperlukan pada saat analisis, juga dokumen dan catatan yang meliputi dokumen pribadi dan dokumen resmi. Data sekunder juga diperoleh melalui studi literature dan dokumentasi. Teknik analisis data dengan cara reduksi data, sajian data, dan penarikan kesimpulan. Untuk uji keabsahan data adalah dengan triangulasi metode maksudnya adalah metode yang dipakai dalam pengumpulan datanya berusaha mendapatkan informasi yang sama dari metode yang satu dengan metode yang lain. Sedangkan triangulasi teori adalah analisis datanya di kritisi lebih dari satu teori karena sebagai rival explanation dan kevalidan data yang akan didapatkan dari penelitian ini.

\section{Temuan dan Pembahasan}

Iklan suatu media one way communication sifatnya untuk mempengaruhi atau mempersuasi para khalayak sebagai penonton atau penikmat iklan. Salah satu unsur dalam iklan untuk mempersuasif khalayak adalah produser iklan bersama tim kreatifnya menampilkan kearifan lokal budaya Madura. Penulis menyampaikan beberapa scene yang terpilih yang merepresentasikan kearifan budaya lokal Madura, kemudian akan melahirkan konstruk dengan sendirinya dari hasil analisis denotatif dan konotatif terhadap iklan tersebut.

\section{Bentuk Syukur Masyarakat Madura}

Scene 0:00/0:29: Denotasi, Gambar diambil pada siang hari secara long shot secara menyeluruh yaitu objek dan sekitar objek terlihat secara keseluruhan. Pada adegan scene ini terlihat pertunjukkan karapan sapi yaitu sapi dengan lari cepat bersama penunggangnya, dan berada di lapangan karapan sapi. Di sekitarnya dipenuhi oleh para penonton karapan sapi yang rata-rata laki-laki, bapak-bapak, remaja, dan anak-anak. Tentu saja mereka adalah penonton yang hobby melihat karapan sapi. Karapan sapi ini adalah merupakan salah satu kebudayaan Madura karena terlihat dari ciri khasnya yaitu sapinya berwarna coklat, setiap perlombaan 
mereka sebelumnya fashion di lapangan lengkap dengan asesorisnya yaitu dari badan hingga kepala begitu pula dengan penunggang karapan sapinya. Para penunggang karapan sapi memakai odeng (tutup kepala yang melingkar) dan kaos berbergaris horizontal dua warna merah dan putih, kemudian memakai baju yang membuka tanpa dikancing dan celana warna hitam dibawah lutut.

Karapan sapi di Madura, tentu sudah tidak asing dengan perlombaan balap asli dalam negeri tersebut. Karapan sapi merupakan perlombaan yang terkesan beda dan merupakan ciri khas dari Pulau Madura. Dalam perlombaan ini, sepasang sapi menarik kereta kayu dan ditunggangi oleh seorang joki, mereka beradu cepat dengan pasangan sapi lain. Pangeran Katandur, disebut-sebut sebagai pencetus pertama lomba karapan sapi ini. Beliau berasal dari Pulau Sapudi, Sumenep. Berawal dari berhasilnya beliau memanfaatkan tenaga sapi untuk merubah tanah yang tandus menjadi subur. Melihat keberhasilannya, para warga Pulau Sapudi mengikuti langkahnya dan tanah Pulau Sapudi yang gersang pun menjadi tanah yang benar-benar subur dan dapat ditanami padi, sehingga hasil panen pun melimpah serta menjadi daerah yang subur dan makmur. Untuk merayakan kegembiraan atas keberhasilan tersebut, Sayyid Ahmad Baidawi atau yang dikenal sebagai Pangeran Katandur itu menggagas untuk mengadakan lomba balapan sapi. Hingga sekarang budaya tersebut masih dijaga dan dilestarikan. (Sejarah karapan sapi).

Konotasi/Ideologi/Mitos yang terkandung dalam gambar scene tersebut bahwa karapan sapi merupakan kebudayaan Madura, adalah yang keberadaannya mempunyai sejarah sangat positif, sapi bukan hanya sebagai hewan mamalia dan pemakan rumput. Tetapi di pulau Madura sapi sebagai alat untuk membajak lahan yang tandus menjadi subur sehingga bisa ditanami padi. Bentuk idiologinya adalah keberhasilan itu diwujudkan dengan perlombaan/karapan sapi yang disampaikan sebagai rasa bersyukurnya masyarakat Madura akan keberhasilan hasil panen padi. Salah satu kearifan lokal ini sampai sekarang turun temurun dari remaja hingga anak-anak penyuka karapan sapi.

\section{Karapan Sapi adalah Simbol Budaya Madura}

Scene: 0:07/0:29: Denotasi, gambar diambil pada siang hari, secara Close Up, terlihat gambar wajah sapi lengkap dengan asesoris di wajah sapi itu, terlihat sangat jelas pada kamera Hand phone Samsung Gading yang berwarna hitam. Sutradara iklan tersebut bermaksud mengiklankan bahwa hasil dari bidikan kamera Hand Phone Samsung tidak mengecewakan karena jelas hasilnya. Salah satu adegan persuasi yang dilakukan tim kreatif iklan tersebut.

Makna Konotasi/Idiologinya adalah karapan sapi adalah maskot kebudayaan Madura. Gambar kepala sapi dengan wajah sapi yang terlihat bahagia dan siap di foto karena tidak ada perlawanan dari sapi, diambil secara Close Up menunjukkan bahwa selain mempersuasif penonton iklan, hasil kameranya jelas, sekalian menunjukkan objek foto adalah karapan sapi yang merupakan simbol budaya Madura paling menonjol di antara kearifan lokal budaya Madura lainnya.

\section{Karapan Sapi, Pakaian Adat Madura, dan Bahasa Madura sebagai Kearifan Budaya Lokal Madura}

Scene 0:16/0:29: Denotasi, gambar diambil siang hari secara Medium Shot, emaknya Kadir tiba-tiba datang dengan memakai pakaian khas perempuan Madura yaitu Kebaya berwarna krem kancing depan dan sarung corak batik Madura di bawah lutut, sambil lari-lari kearah Kadir di mana sedang berbincang dengan Gading dan Giselle tentang hand phone Samsung Galaxy. Dengan logat bahasa Maduranya emaknya Kadir berbicara dengan Kadir sambil memijat-mijat sapinya Kadir "kon ngerti jet pijetnya kalo gak menang make beli smart phone pake apa?”...., Kadir menjawab pertanyaan emaknya "yah pake uang Kadir mak...." Kemudian sapi Kadir secara spontan seolah-olah mendengar percakapan Kadir dengan emaknya "buwaaa..." (suara sapi) gambar diambil secara Close Up pada wajah sapi yang sedang mengeluarkan suara bunyi sapi pada umumnya. Kemudian Kadir bilang ke emaknya "tuh mak setuju..." seolah-olah sapi Kadir menyetujui bahwa Kadir akan membelikan smart phone emaknya dengan uang kemenangannya, gambar diambil Medium Shot. Kemudian terdengar suara Gading dan 
Giselle ketawa bareng mendengar Kadir bilang ke emaknya tentang sapinya setuju.

Konotasi/ideologi yang terkadung dalam adegan ini adalah dengan kearifan lokal budaya Madura seperti pakaian Madura, karapan sapi, dan logat bahasa Madura merupakan icon yang menarik dalam sebuah periklanan.

\section{E. Penutup}

Kearifan lokal budaya Madura dalam tulisan ini direpresentasikan melalui iklan bandphone Samsung Galaxy versi Gading dan Giselle. Riset ini menggunakan analisis semiotika komunikasi Roland Barthes. Penulis menemukan beberapa ideologi/konstruk yang terbangun di dalam sebuah iklan tersebut. Pertama, bentuk syukur masyarakat Madura yaitu menurut sejarah jika hasil panen padinya masyarakat Madura berhasil melimpah, maka rasa syukur mereka dengan mengadakan karapan sapi bersamasama. Kedua, karapan sapi simbol budaya Madura, maksudnya dalam analisis ini adalah diperlihatkan secara close up ini menunjukkan bahwa karapan sapi merupakan simbol kebudayaan masyarakat Madura. Ketiga, karapan sapi, pakaian adat Madura, Bahasa Madura merupakan kearifan lokal budaya Madura, dalam iklan ini ditampilkan secara lengkap terlihat dalam scene tersebut adalah sapinya Kadir lengkap dengan busananya ala Madura, pakaian Kadir dan Ibunya merupakan ciri khas orang Madura, begitu pula dengan bahasa yang mereka pakai, sangat kental dengan logat Madura yang memiliki suara maupun logat tersendiri. Apabila ada orang luar dari Madura jika mendengarkan percakapan orang Madura pasti mereka tahu bahwa logat Madura seperti itu. Ini juga diperkenalkan lawak dalam group "Srimulat" pada waktu itu sangat fenomenal yaitu sosok lakon "Kadir" bagaimana dia berperan seperti orang Madura, pakaiannya, dan logat bahasanya yang kata-katanya sering di ulang-ulang seperti dialog antara emak dan Kadir lam iklan hand phone yang dimaksud penulis yaitu "jet pijet".

Kesimpulannya, kearifan lokal budaya Madura bisa diperkenalkan melalui Iklan handphone Samsung Galaxy, yang sebelumnya juga diperkenalkan oleh iklan Djarum 76 yang diperankan oleh aktor Dony Damara. Ini juga mempunyai pesan bahwa Indonesia sangat kaya akan kearifan lokal kebudayaan suatu kepulauan salah satunya adalah pulau Madura. Sangat ulet dengan karakter budayanya yaitu karapan sapi, pakaian adat Madura, Bahasa, dan logat Madura.

\section{Daftar Pustaka}

Barthes, Roland. 2007. Membedah Mitos-Mitos Budaya Massa: Semiotika atau Sosiologi Tanda, Simbol, dan Representasi. Yogyakarta. Jalasutra.

Basarah, Finy Fitrya. 2006. Poligami Dalam Media Film Indonesia (Analisis Semiotika Roland Barthes Film "Berbagi Suami"). Universitas Padjadjaran Bandung. Pogram Pascasarjana Program Studi Ilmu Komunikasi.

Berger, Arthur Asa. 1982. Media Analysis Techniques. Beverly Hills/London. Sage Publication.

Beritateknologi.com, 2013. Prosentase Pengguna Hand Phone Samsung Galaxy. http://www.beritateknologi. $\mathrm{com} / 80$-persen-pemilik-smartphonedi-indonesia-menggunakan-handphonepintar-dari-samsung/, akses 9 Desember 2014, 10.35 .

Eryanto. 2005. Analisis Wacana: Pengantar Analisis Teks Media, Cetakan Keempat, Yogyakarta. PT. LKIS Pelangi Aksara.

Ina, 2014, http://www.eastjava.com/ tourism/pasuruan/ina/bull-race.html, 7 Desember 2014, 4:52.

Kurniawan. 2001. Semiologi Roland Barthes. Magelang. Indonesia Tera.

Lubis, Farhan Azis, 2014. Pengertian Kearifan Lokal. http://pangeranarti.blogspot. com/ 2014/11/pengertian-kearifanlokal-lengkap.html, 6 Desember 2014, $3: 53$

Rivers, William L, Jay W.Jensen, \& Theodore Peterson. 2004. Media Massa dan Masyarakat Modern. Jakarta. Prenada Media.

Sharff, Stefan. 1982. The Element Of Cinema: Toward a Theory of Cinesthetic Impact. New York. Columbia University Press. 
Sobur, Alex. 2003. Semiotika Komunikasi. Cetakan Pertama. Bandung. PT. Remaja Rosdakarya.

Sobur, Alex. Semiotika Dalam Tafsir "Harry Potter". Disampaikan dalam Seminar Ilmiah Intern (SII) Dosen Fakultas Ilmu Komunikasi Universitas Islam Bandung. 24 Mei 2006.

2004. Semiotika Komunikasi. Cetakan Kedua. Bandung. PT. Remaja Rosdakarya.
Wahyuningsih, Sri, 2013. Desain Komunikasi Visual, Bangkalan, UTM Press.

Wahyuningsih, Sri. 2009. Pesan-Pesan Dakwah Dalam Media Film Indonesia (Analisis Semiotika Roland Barthes Terbadap Film "99 Cahaya Di Langit Eropa). Universitas Padjadjaran Bandung. Program Pascasarjana Program Studi Ilmu Komunikasi. 